\title{
Membangun Perpustakaan Digital Pada Madrasah Aliyah Negeri (MAN) 1 Sumbawa Besar
}

Suhardiman ${ }^{1}$, Dwinita Arwidiyarti², Maspaeni ${ }^{3}$, Belsana Butar Butar ${ }^{4}$

\author{
STMIK Mataram ${ }^{1,2,3}$ \\ AMIK BSI Jakarta 4 \\ dwinita.arwidya@gmail.com
}

\begin{abstract}
Perpustakaan mempunyai peranan penting dalam hal menyediakan informasi yang berkaitan dengan pengetahuan dan merupakan unsur penting dalam lembaga pendidikan. Keberhasilan dalam peningkatan efisiensi dan efektifitas pendidikan dapat didukung dengan kehadiran perpustakaan. Perpustakaan yang ada di MAN 1 Sumbawa Besar adalah perpustakaan non digital, di mana anggotanya adalah guru dan siswa yang ada di lingkungan MAN 1 Sumbawa Besar. Masalah yang muncul pada perpustakaan tersebut adalah adanya keterbatasan jumlah buku yang dimiliki sehingga seringkali buku yang akan dipinjam stoknya kosong di perpustakaan karena sedang dipinjam oleh peminjam lainnya, selain itu juga adanya batasan hari dan waktu layanan perpustakaan sehingga peminjaman buku hanya dapat dilakukan pada hari dan jam kerja. Untuk dapat mengakomodir kebutuhan akan buku dan tingginya minat baca pada guru dan siswa MAN 1 Sumbawa Besar maka aplikasi perpustakaan digital adalah solusi yang tepat. Aplikasi ini dibangun dengan menggunakan metode System Development Life Cycle (SDLC) yang merupakan metodologi klasik yang digunakan untuk mengembangkan, memelihara dan menggunakan sistem informasi yang terdiri atas beberapa tahapan yaitu tahap perencanaan, analisis, perancangan, seleksi, penerapan dan pemeliharaan. di mana perancangan sistemnya dibuat dengan menggunakan Flowchart Sistem untuk menggambarkan alur dari sistem yang dirancang dan Usecase Diagram untuk menggambarkan menu-menu yang dapat diakses oleh user. Perancangan database dibuat dengan menggunakan Entity Relationship Diagram yang menghasilkan 5 (lima) tabel yaitu Tabel User, Tabel Jenis, Tabel File, Tabel Kategori dan Tabel Ebook. Output tercetak yang dihasilkan berupa Laporan Data Anggota, Laporan Data File dan Laporan Data Ebook untuk diserahkan kepada Kepala Sekolah setiap bulan sekali. Dengan aplikasi perpustakaan digital ini perpustakaan pada MAN 1 Sumbawa Besar akan dapat meningkatkan pelayanannya kepada anggota dan juga pada pihak lain yang bukan anggota perpustakaan dengan menyediakan ebook dan file yang dapat diunduh kapanpun tanpa dibatasi jam layanan dan tanpa batasan stok buku fisik.
\end{abstract}

Kata Kunci : perpustakaan, perpustakaan digital

\section{Latar Belakang}

Internet memegang peranan yang sangat penting terutama dalam pemenuhan kebutuhan informasi yang akurat dan cepat dalam segala bidang termasuk pada perpustakaan. Perkembangan perpustakaan digital tidak lepas dari perkembangan teknologi informasi. Perpustakaan digital dibangun di atas teknologi web, yang memungkinkan pengaksesan koleksi buku oleh anggota, kapan dan di manapun posisi pengguna berada melalui media internet. Madrasah Aliyah Negeri (MAN) 1 Sumbawa Besar adalah salah satu Madrasah Aliyah Negeri yang ada di Kabupaten Sumbawa Besar dengan jumlah siswa 600 orang dan jumlah guru sebanyak 63 orang. Perpustakaan yang ada di MAN 1 Sumbawa Besar adalah perpustakaan non digital, di mana anggotanya adalah guru dan siswa yang ada di lingkungan MAN 1 Sumbawa Besar dengan buku fisik yang diperpinjamkan sesuai dengan ketentuan peminjaman yang telah ditentukan. Selain itu juga sistem peminjaman dan pengembalian buku pada perpustakaan MAN 1 Sumbawa Besar masih manual sehingga hanya mengandalkan pencatatan pada buku besar peminjaman dan kartu slip buku.

Masalah yang muncul pada perpustakaan tersebut adalah adanya keterbatasan jumlah buku yang dimiliki sehingga seringkali buku yang akan dipinjam stoknya kosong di perpustakaan karena sedang dipinjam oleh peminjam lainnya, selain itu juga adanya batasan hari dan waktu layanan perpustakaan sehingga peminjaman buku hanya dapat dilakukan pada hari dan jam kerja. Sistem peminjaman yang masih manual juga membuat pekerjaan petugas perpustakaan menjadi tidak praktis karena harus mencatat data peminjaman dan pengembalian pada buku besar peminjaman dan kartu slip buku dan pada saat pembuatan laporan peminjaman bulanan datadata yang ada pada buku besar peminjaman tersebut harus diinputkan ke dalam format Microsoft Excel. Kondisi ini selain tidak praktis juga memungkinkan laporan peminjaman buku bulanan yang dihasilkan tidak akurat karena kesalahan dalam menginputkan data (human error) yang tinggi.

Berdasarkan beberapa permasalah tersebut, maka solusi yang dibutuhkan oleh MAN 1 Sumbawa Besar adalah sebuah aplikasi perpustakaan digital karena dengan adanya perpustakaan digital buku yang diperpinjamkan adalah dalam bentuk electronic book sehingga selalu tersedia dan dapat diunduh setiap saat. Oleh karena itu maka rumusan masalah pada penelitian ini adalah bagaimana cara membangun perpustakaan digital yang nantinya akan diimplementasikan di Perpustakaan MAN 1 Sumbawa Besar yang dapat meningkatkan layanan yang diberikan oleh petugas perpustakaan baik kepada anggota perpustakaan maupun kepada Kepala Perpustakaan dan Kepala Sekolah MAN 1 Sumbawa Besar. 


\section{Kajian Pustaka \\ a. Perancangan Sistem}

Perancangan sistem adalah tahapan yang bertujuan untuk memberikan gambaran secara umum kepada user tentang sistem yang baru. Perancangan sistem mengidentifikasikan komponen-komponen sistem informasi yang akan dirancang secara rinci. (Hartono, 1999 : 209).

\section{b. Perpustakaan Digital}

Beberapa pengertian tentang perpustakaan digital, sebagai berikut :

1) Perpustakaan digital adalah perpustakaan modern yang sudah menggunakan sistem otomasi dalam operasionalnya serta mempunyai koleksi bahan pustaka sebagian besar dalam bentuk format digital yang disimpan dalam arsitektur komputerisasi dan bisa diakses melalui komputer. Koleksi dari perpustakaan digital adalah dokumen digital umumnya terdiri dari lima jenis yaitu teks, gambar, suara, gambar bergerak (video) dan grafik (Susanto : 2010).

2) Perpustakaan Digital adalah sebuah sistem yang memiliki berbagai layanan dan obyek informasi yang mendukung akses obyek informasi tesebut melalui perangkat digital. Tumbuhnya perpustakaan digital disebabkan oleh beberapa pemikiran. Perpustakaan digital juga memliki kelemahan dan keunggulan. Kebutuhan dalam perpustakaan digital adalah perangkat keras, perangkat lunak, dan jaringan komputer sebagai elemen-elemen penting infrastruktur sebuah perpustakaan digital. Namun, perangkat utama yang diperlukan dalam perpustakaan digital adalah komputer personal (PC), internet (internetworking) dan World Wide Web (WWW). Ketiga hal tersebut memungkinkan adanya perpustakaan digital. (Saepuloh : 2016).

3) Perpustakaan digital adalah suatu perpustakaan yang menyimpan data buku (tulisan) dalam bentuk file elektronik dan mendistribusikannya dengan menggunakan protokol elektronik melalui jaringan komputer. Pada sebuah perpustakaan digital terdapat beberapa komponen utama yang sangat penting, yaitu: Admin, Buku (Buku fisik dan Non Fisik), File, Pengguna Layanan, Sistem Peminjaman dan Pemesanan Buku Di Perpustakaan Digital, Sistem Download Di Perpustakaan Digital (Mahedy : 2009).

\section{c. Metodologi Pengembangan Sistem.}

Pengembangan sistem dapat berarti menyusun sistem yang baru untuk menggantikan sistem yang lama secara keseluruhan atau memperbaiki sistem yang telah ada. Sistem yang lama perlu diperbaiki karena adanya permasalahan-permasalahan yang timbul di sistem yang lama.

Siklus hidup pengembangan sistem (System Development Life Cycle/SDLC)) merupakan metodologi klasik yang digunakan untuk mengembangkan, memelihara dan menggunakan sistem informasi. Metode ini menggunakan pendekatan sistem yang disebut pendekatan air terjun (Waterfall Approach), yang menggunakan beberapa tahapan dalam mengembangkan sistem (Hartono, 1999 : 52). Adapun tahapan dalam SDLC adalah :

1. Tahap Perencanaan Sistem (System Planning). Tahap perencanaan adalah tahap awal pengembangan sistem yang mendefinisikan perkiraan kebutuhan-kebutuhan sumber daya seperti perangkat fisik, manusia, metode (teknik dan operasi), dan anggaran yang sifatnya masih umum (belum detail/rinci)

2. Tahap Analisis Sistem (System Analysis). Tahap analisis sistem adalah tahap penelitian atas sistem yang telah ada dengan tujuan untuk merancang sistem yang baru atau diperbarui.

3. Tahap Perancangan/Desain Sistem (System Design). Tahap desain sistem adalah tahap setelah analisis sistem yang menentukan proses dan data yang diperlukan oleh sistem baru. Desain sistem dibedakan menjadi dua macam, yaitu desain sistem umum dan desain sistem terinci.

4. Tahap Seleksi Sistem (System Selection). Tahap seleksi sistem merupakan tahap untuk memilih perangkat keras dan perangkat lunak untuk sistem informasi.

5. Tahap Penerapan/Implementasi Sistem (System Implementation). Tahap implementasi atau penerapan adalah tahap dimana desain sistem dibentuk menjadi suatu kode (program) yang siap untuk dioperasikan.

6. Tahap Pemeliharaan/Perawatan Sistem. Tahap pemeliharaan/perawatan sistem merupakan tahap yang dilakukan setelah tahap implementasi yang meliputi penggunaan sistem, audit sistem, penjagaan sistem, perbaikan sistem dan peningkatan sistem.

\section{d. Penelitian Terdahulu}

Penelitian mengenai aplikasi perpustakaan digital berbasis web telah dilakukan oleh beberapa peneliti terdahulu, diantaranya adalah Mahedy yang melakukan penelitian di Perpustakaan Jurusan Pendidikan Dasar Universitas Pendidikan Ganesha pada tahun 2009. Aplikasi perpustakaan digital berbasis web yang dihasilkan mempunyai 2 (dua) pengguna yaitu administrator dan user. Di mana user adalah Dosen dan mahasiswa yang telah terdaftar. Kategori yang disajikan adalah Buku Teks, Buku Ajar, Buku Kelas, Jurnal, Modul PJJ dan Laporan PPL Mahasiswa. Penelitian serupa juga telah dilakukan oleh Nogroho di SMA Negeri 5 Semarang pada tahun 2011, di mana pengguna terdiri atas administrator dan user. User adalah guru dan siswa yang telah terdaftar. Data pustaka yang disajikan adalah koleksi buku fisik dan buku non fisik. Perbedaan antara 2 (dua) penelitian terdahulu tersebut dengan penelitian ini terletak pada usernya. Di mana user terdiri atas 3 (tiga) yaitu administrator, pengunjung dan anggota. Pengunjung adalah semua orang yang mengujungi laman perpustakaan digital dan anggota adalah pengunjung perpustakaan digital yang terdiri atas guru dan siswa yang telah terdaftar. Kedua user tersebut memiliki hak akses yang berbeda. Buku dan artkel yang dapat diunduh oleh pengunjung jumlahnya terbatas, 
sementara anggota setelah login dapat mengunduh semua buku dan artikel yang tersedia.

\section{e. Perangkat Pendukung Sistem}

Perangkat pendukung yang digunakan di dalam merancang sistem adalah Flowchart Sistem yang digunakan untuk menggambarkan alur sistem, Unified Modeling Language (UML) yang berupa Usecase Diagram yang digunakan untuk menggambarkan menumenu yang ada di dalam sistem, sedangkan untuk perancangan database menggunakan Entity Relationship Diagram. Bahasa pemrograman, database dan aplikasi pendukung yang digunakan untuk membangun sistem ini adalah : Hypertext Markup Language (HTML) yang merupakan suatu bahasa pemrograman untuk membangun sebuah dokumen dalam bentuk halaman di web, PHP (Hypertext Preprocessor) yang merupakan salah satu bahasa pemrograman web yang paling dikenal saat ini dan World Wide Web (WWW) atau yang lebih dikenal dengan nama web yang merupakan salah satu layanan yang didapat oleh pemakai komputer yang terhubung ke internet.

\section{Perancangan Sistem}

\section{1) Flowchart Sistem}

Alur sistem dirancang dengan menggunakan Flowchart Sistem, seperti gambar 1 berikut :

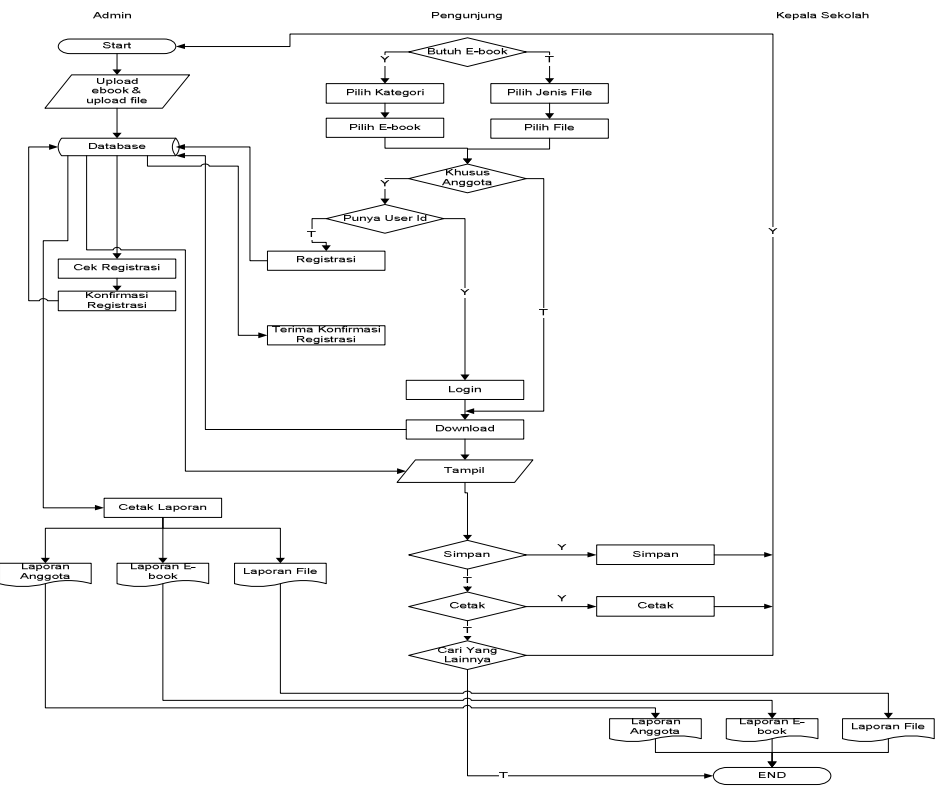

Gambar 1. Flowchart Sistem Baru

Admin melakukan proses unggah e-book dan file ke dalam database dan mempublishnya ke dalam sistem. Pengunjung dapat memilih kategori, ebook dan file yang dibutuhkan untuk diunduh, disimpan dan dicetak. Tidak semua ebook dan file dapat diunduh oleh pengunjung, sedangkan anggota perpustakaan yang telah terdaftar dapat mengunduh seluruh ebook dan file yang tersedia setelah melakukan login. Setiap sebulan sekali admin mencetak Laporan Data Anggota, Laporan Data Ebook dan Laporan File yang tersedia untuk diberikan kepada Kepala Sekolah MAN 1 Sumbawa Besar.

\section{2). Unified Modelling Language}

Use Case Diagram merupakan diagram yang menggambarkan menu-menu yang dapat diakses oleh actor (pengguna) baik administrator (admin) maupun end user.

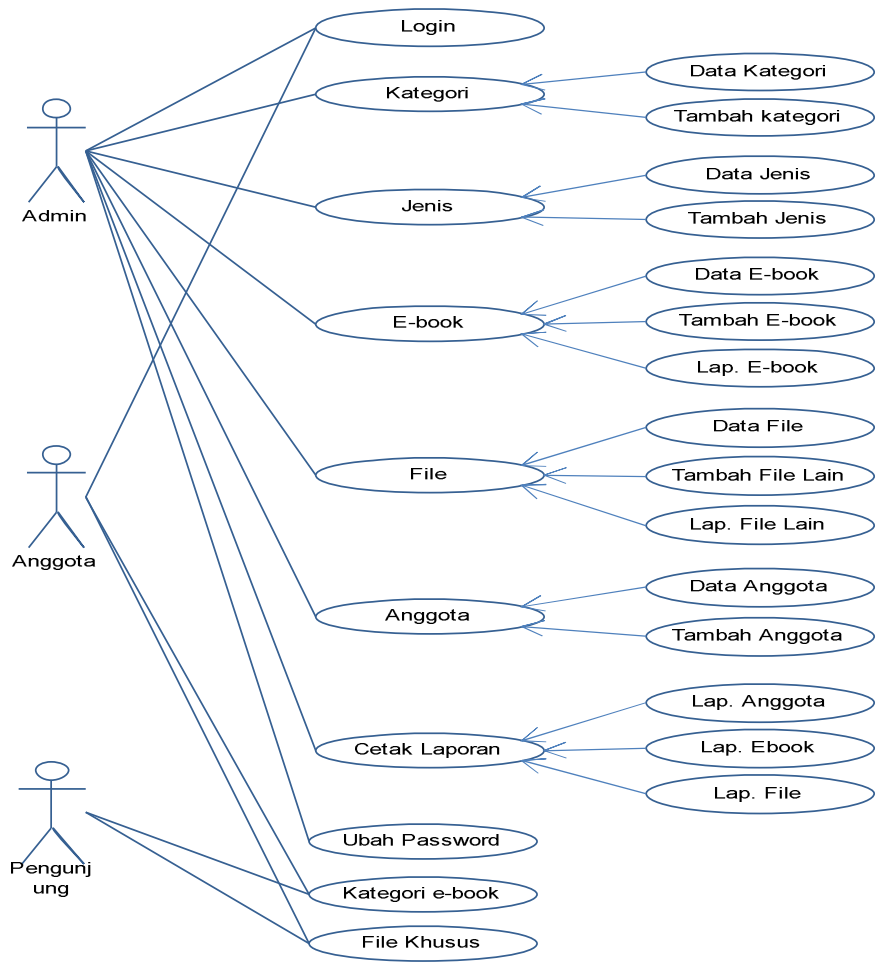

Gambar 2. Use Case Diagram

Pada gambar 2 Admin memiliki hak akses terhadap beberapa menu yaitu login, kategori, jenis, ebook, file, anggota, cetak laporan dan ubah password. Anggota memiliki hak akses terhadap menu login, kategori ebook dan file khusus sedangkan pengunjung memiliki hak akses terbatas pada kategori ebook dan file khusus, pengunjung tidak login.

\section{3). Entitiy Relationship Diagram (ERD)}

Perancangan database dilakukan dengan menggunakan Entity Relationship Diagram. Dihasilkan 5 (lima) buah tabel yaitu tabel jenis, tabel file, tabel kategori, tabel ebook dan tabel user sebagai gambar 3 berikut : 
$[1,1]$

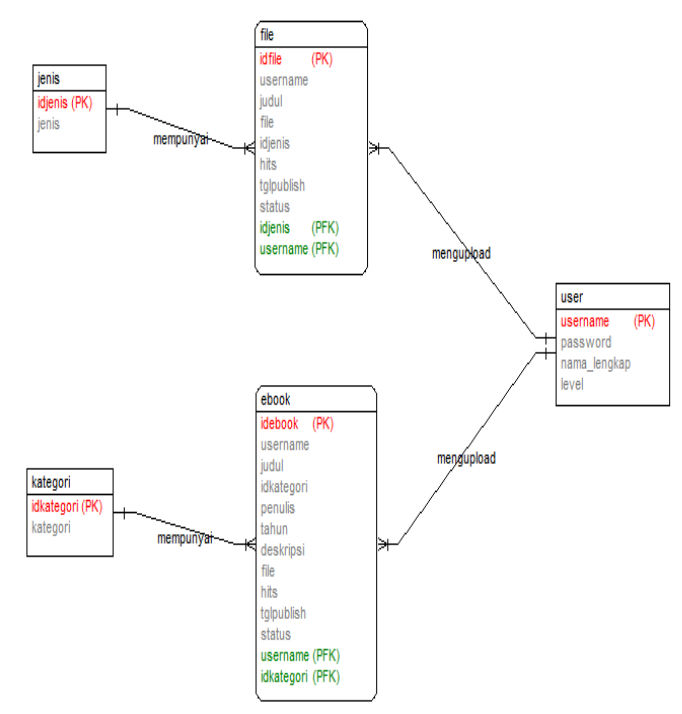

Gambar 3. Entity Relationship Diagram

\section{Implementasi Sistem dan Hasil}

Implementasi sistem adalah tahapan dalam pengembangan sistem yang berupa implementasi program yang telah dibangun. Berikut adalah beberapa tampilan layar yang dihasilkan :

1). Tampilan Home Admin

Home Admin akan tampil setelah admin berhasil login dengan menginputkan username dan password pada form login. Pada Home Admin terdapat beberapa menu yang dapat dipilih, yaitu : kategori, jenis, ebook, file khusus, anggota, cetak laporan dan ubah password seperti gambar 4 berikut :

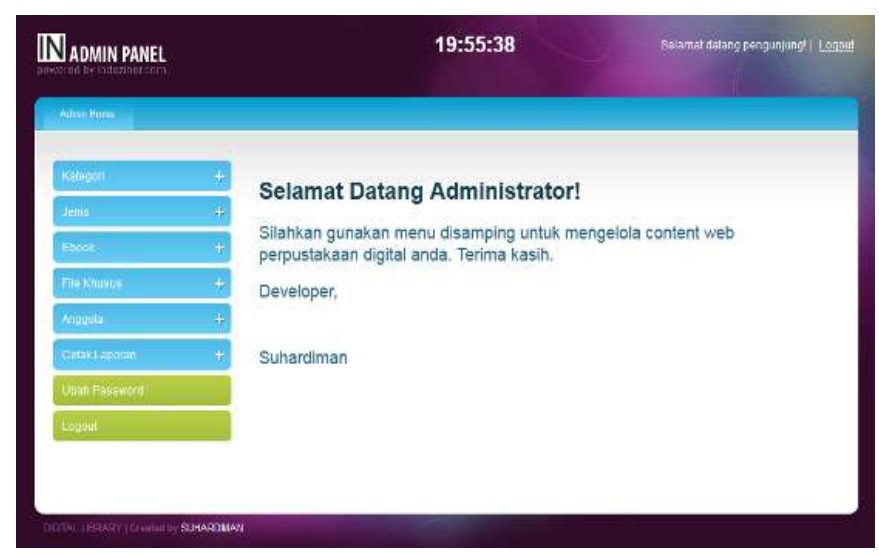

Gambar 4. Tampilan Home Admin

\section{2). Tampilan Menu Kategori}

Jika menu kategori dipilih maka terdapat 2 (dua) pilihan sub menu yaitu data kategori dan tambah kategori, Jlka submenu data kategori dipilih maka akan tampil Form Data Kategori dengan pilihan aksi ubah dan hapus. Jika ingin melakukan perubahan terhadap data kategori maka pilihlah data kategori yang akan diubah kemudian pilih aksi ubah dan akan tampil form ubah data kategori. Jika ingin menghapus data kategori maka pilih data kategori yang akan dihapus dan kemudian pilih aksi hapus maka data kategori akan terhapus. Jika submenu tambah kategori dipilih maka akan tampil form tambah kategori untuk menginputkan data kategori yang akan ditambahkan seperti gambar 5 berikut.

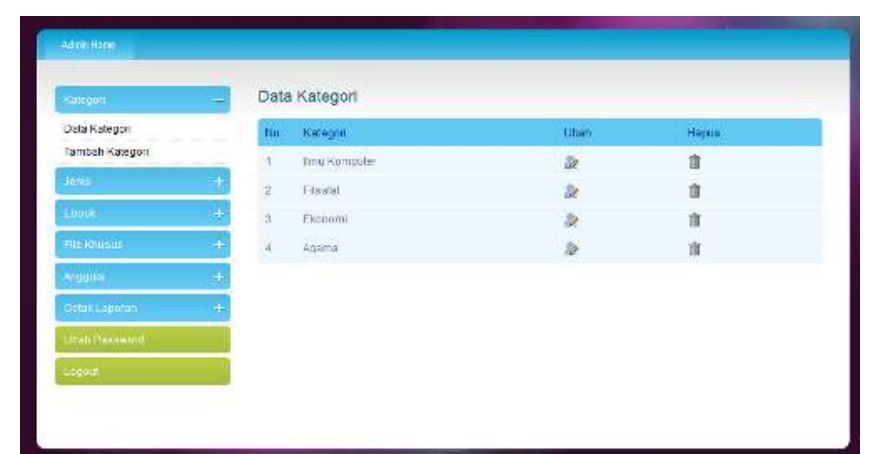

Gambar 5. Tampilan Menu Data Kategori

\section{3). Tampilan Menu Jenis}

Jika menu jenis dipilih maka terdapat 2 (dua) pilihan sub menu yaitu data jenis dan tambah jenis, Jlka submenu data jenis dipilih maka akan tampil Form Data jenis dengan pilihan aksi ubah dan hapus. Jika ingin melakukan perubahan terhadap data jenis maka pilihlah data jenis yang akan diubah kemudian pilih aksi ubah dan akan tampil form ubah data jenis. Jika ingin menghapus data jenis maka pilih data jenis yang akan dihapus dan kemudian pilih aksi hapus maka data jenis akan terhapus. Jika submenu tambah jenis dipilih maka akan tampil form tambah jenis untuk menginputkan data jenis yang akan ditambahkan seperti pada gambar 6.

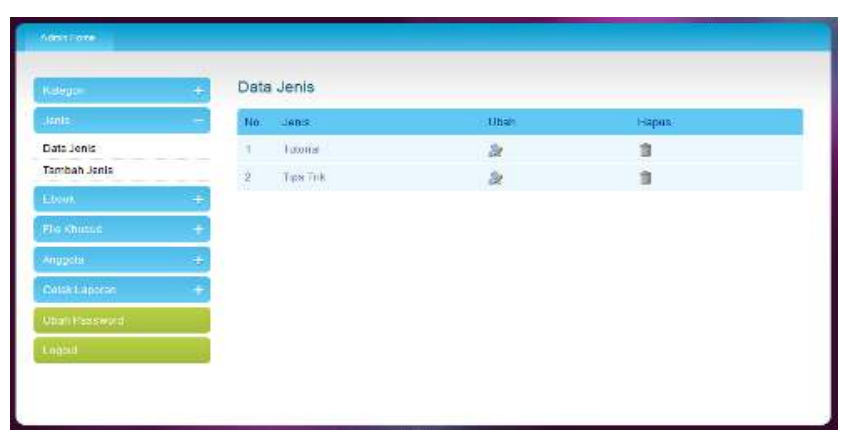

Gambar 6 Tampilan Menu Data Jenis

\section{4). Tampilan Menu Data Ebook}

Pada menu data ebook terdapat 3 (tiga) sub menu yaitu data ebook, tambah ebook dam laporan ebook. Jika data ebook dipilih maka akan tampil data ebook yang telah tersedia. Jika tambah ebook dipilih maka akan tampil form tambah ebook untuk menginputkan data ebook yang akan ditambahkan. Jika laporan ebook dipilih maka akan tampil laporan ebook yang berisi daftar ebook yang telah tersedia. Berikut adalah tampilan menu data ebook : 


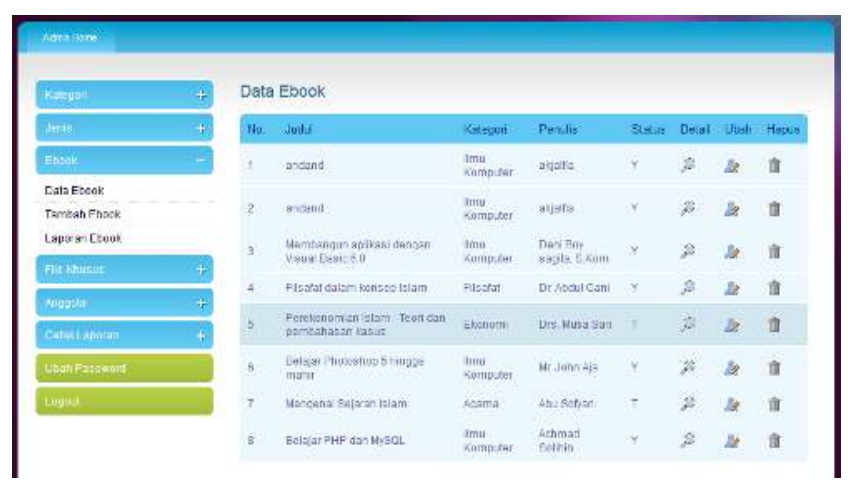

Gambar 7. Tampilan Menu Data Ebook

Berikut adalah output tercetak yang dihasilkan dari aplikasi perpustakaan digital ini seperti ditunjukan pada gambar 8,9 dan 10 :

a) Laporan Data Ebook

\begin{tabular}{|c|c|c|c|c|c|c|c|c|}
\hline \multicolumn{9}{|c|}{ Laporan Data Ebook } \\
\hline No. & Judul & Kategori & Penulis & Tahun & Publish & Nama File & Didownload & $\begin{array}{l}\text { Tanggal } \\
\text { Upload }\end{array}$ \\
\hline 1 & andand & $\begin{array}{l}\text { Ilmu } \\
\text { Komputer }\end{array}$ & abjallfa & 2001 & $\mathrm{Y}$ & SBD1Pertemuan10dan11.pdf & dfl 1 kali & 27 April 2014 \\
\hline 2 & andand & $\begin{array}{l}\text { Ilmu } \\
\text { Komputer }\end{array}$ & akjallta & 2001 & $\mathrm{Y}$ & SBD1Pertemuan 10dan11.pdf & df 1 kali & 27 April 2014 \\
\hline & $\begin{array}{l}\text { Membangun aplikasi dengan Visual } \\
\text { Basic } 6.0\end{array}$ & $\begin{array}{l}\text { Ilmu } \\
\text { Komputer }\end{array}$ & $\begin{array}{l}\text { Deni Boy sagita, } \\
\text { S.Kom }\end{array}$ & 2014 & $\mathrm{Y}$ & krisna-rb6-01.zip & 4 kali & $\begin{array}{l}03 \text { Februari } \\
2014\end{array}$ \\
\hline 4 & Filsafat dalam konsep Islam & Filisafat & Dr. Abdul Gari & 2010 & $\mathrm{Y}$ & TES2. docx & 17 kali & $\begin{array}{l}01 \text { Februari } \\
2014\end{array}$ \\
\hline & $\begin{array}{l}\text { Perechonomian Islam - Teori dan } \\
\text { pembahasasn kasus }\end{array}$ & Ekonomi & Drs. Mutia Sari & 2010 & $\mathrm{~T}$ & TES7.pdf & Okali & $\begin{array}{l}01 \text { Januari } \\
2014\end{array}$ \\
\hline 6 & Belajar Photoshop 5 hingga mahir & $\begin{array}{l}\text { IImu } \\
\text { Komputer }\end{array}$ & Mr. John Aja & 2011 & $\mathrm{Y}$ & TESSSS.docx & 0 kali & $\begin{array}{l}01 \text { Februari } \\
2014\end{array}$ \\
\hline & Mengenal Sejarah Islam & Agama & Abu Sotyan & 2012 & $\mathrm{I}$ & TES3.docx & Okali & $\begin{array}{l}03 \text { Februari } \\
2014\end{array}$ \\
\hline 8 & Belajiju PYP dan NySQL & $\begin{array}{l}\text { Ilmu } \\
\text { Komputer }\end{array}$ & Achmad Solihin & 2013 & Y & ebook-php.pdf & 2 kali & $\begin{array}{l}\text { O1 Februari } \\
2014\end{array}$ \\
\hline
\end{tabular}

Gambar 8. Tampilan Laporan Data Ebook

b). Laporan Data File

\section{Laporan Data File}

\begin{tabular}{|c|c|c|c|c|c|c|}
\hline Sto & Judul & Jenis & Status & Sama File & Iglpul|lish & Didoranlad \\
\hline & & IItorial & Y & tororial prppopte & 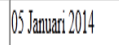 & Okali \\
\hline & thryath & Inpsint & Y & tins doc & O1 Ferourainit & 3kail \\
\hline
\end{tabular}

Gambar 9. Tampilan Laporan Data File

c). Laporan Data Anggota

\section{Laporan Data Anggota}

\begin{tabular}{|l|l|l|}
\hline No & \multicolumn{1}{|c|}{ Username } & \multicolumn{2}{c|}{ Nama Lengkap } \\
\hline 1 & udin & Zaenudinl \\
\hline 2 & anto & Anto lagi \\
\hline 3 & arches & sulhardiman \\
\hline
\end{tabular}

Gambar 10. Tampilan Laporan Data Angoota

5). Tampilan Home Pengunjung dan Anggota

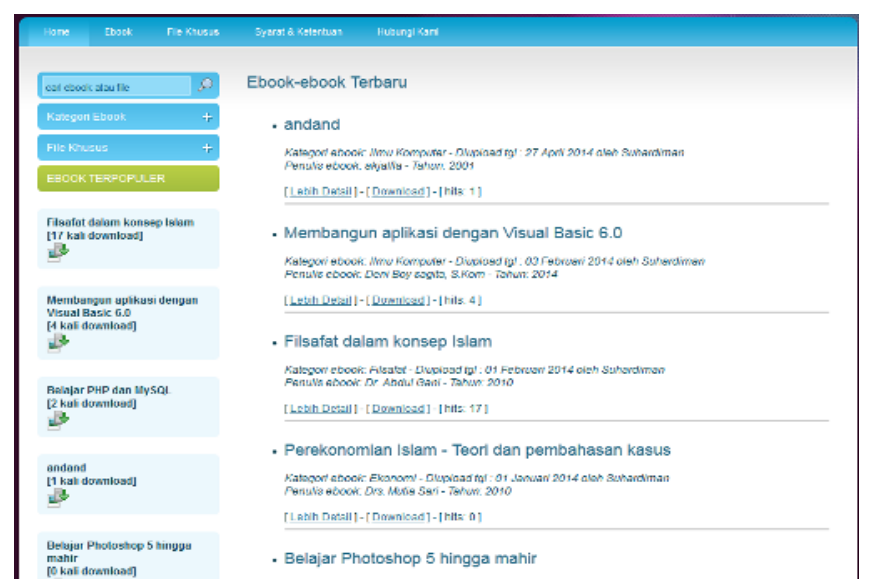

Gambar 12. Tampilan Home Pengunjung dan Anggota

Gambar 12 menunjukan pada home pengunjung dan anggota terdapat beberapa menu yang dapat dipilih yaitu ebook, file khusus, syarat dan ketentuan dan hubungi kami. Selain itu juga terdapat fitur pencarian ebook atau file agar memudahkan dalam pencarian ebook atau file yang dibutuhkan dan ebook terpopuler yang menampilkan daftar ebook yang paling sering diunduh oleh pengunjung.

\section{Kesimpulan}

Kesimpulan yang dapat diambil dari hasil pembahasan pada penelitian ini adalah Aplikasi perpustakaan digital yang dihasilkan dibuat dengan menggunakan metode System Development Life Cycle (SDLC), di mana perancangan sistemnya dibuat dengan menggunakan Flowchart Sistem untuk menggambarkan alur dari sistem yang dirancang dan Usecase Diagram untuk menggambarkan menu-menu yang dapat diakses oleh user. Perancangan database dibuat dengan menggunakan Entity Relationship Diagram yang menghasilkan 5 (lima) tabel yaitu Tabel Jenis, Tabel File, Tabel Kategori, Tabel Ebook dan Tabel User. Output tercetak yang dihasilkan berupa Laporan Ebook, Laporan Data Anggota, Laporan Data File. Dengan aplikasi perpustakaan digital ini perpustakaan pada MAN 1 Sumbawa Besar akan dapat meningkatkan pelayanannya kepada anggota dan juga pada pihak lain yang bukan anggota perpustakaan dengan menyediakan ebook dan file yang dapat diunduh kapanpun tanpa dibatasi jam layanan dan tanpa batasan stok buku fisik.

\section{Daftar Pustaka}

Hartono, Jogiyanto. 1999. Analisis \& Desain Sistem Informasi : Pendekatan Terstruktur Teori dan Praktek Aplikasi Bisnis. Yogyakarta: Andi.

Mahedy, Kadek Surya. 2009. Pengembangan Perpustakaan Digital Berbasis Web di Perpustakaan Jurusan Pendidikan Dasar Universitas Pendidikan Ganesha. JPTK, UNDIKSHA, 6(1), 51 - 62 .

Nugroho, Agung Setyo. 2011. Rancang Bangun Perpustakaan Digital Berbasis Web Pada Sma 
Negeri 3 Semarang. Jurnal Teknologi Informasi dan Komunikasi 2(2), 65-72.

Saepuloh, Dani. 2016. Perpustakaan Elektronik (ELibrary) Menggunakan Calibre. Jurnal Pari 2(2), 9296.

Susanto, Setyo Edi. 2010. Desain Dan Standar Perpustakaan Digital. Jurnal Pustakawan Indonesia 10 (2), 17-23. 